\title{
VALIDATION OF AN IMPROVED EUROPEAN STANDARD METHOD FOR THE DETERMINATION OF PCBS IN OIL SAMPLES
}

\author{
ZDENKA CENCIČ KODBA ${ }^{1}$, DARINKA BRODNJAK VONČINA ${ }^{2}$ \\ ${ }^{1}$ Institute of Public Health Maribor, Environmental Protection Institute, Prvomajska 1, \\ 2000 Maribor, Slovenia (zdenka.kodba@zzv-mb.si) \\ ${ }^{2}$ Faculty of Chemistry and Chemical Engineering, University of Maribor, Smetanova \\ 17, 2000 Maribor, Slovenia (darinka.brodnjak@uni-mb.si)
}

\begin{abstract}
Two European standard methods (EN 12766 and EN 61619) are currently used for the determination of PCBs in specific oil matrix. However, apolar matrix compounds (e.g. hydrocarbons) elute from the adsorbent together with the PCBs and are injected into the analytical system where their presence contaminates the inlet, detectors and columns; and decreases system performances. Insufficient cleanup causes delay of elution of PCBs from GC columns.

By using new sulfoxide-bonded silica, PCBs are better separated from aliphatic hydrocarbons because the specificity of the stationary phase for these compounds is much higher that that used in both standard methods. A gas chromatograph AT6890 with two capillary columns of different polarities (HP-5MS and $\mathrm{DB}-1701)$ coupled to two $\mu \mathrm{ECDs}$ is used. Oven temperature program is as followed: $90^{\circ} \mathrm{C}(1 \mathrm{~min})$, $70^{\circ} \mathrm{C} / \mathrm{min}$ to $180^{\circ} \mathrm{C}, 5^{\circ} \mathrm{C} / \mathrm{min}$ to $230^{\circ} \mathrm{C}(0.1 \mathrm{~min}), 1.5^{\circ} \mathrm{C} / \mathrm{min}$ to $280^{\circ} \mathrm{C}$. Run time is $46 \mathrm{~min}$.

The procedure was validated through regular analysis of blanks, fortified samples (transformer oil, motor used and unused oil) and certified materials (BCR-449 and BCR-420, waste mineral oils, high and low PCB levels). Two internal standards were used (PCB 30 and PCB 209). An average recovery \pm RSD of $82.8 \pm 5.4$ $\%$ was achieved for all six PCBs in different matrices. The LOQ per single PCB congener is $0.2 \mathrm{mg} \mathrm{kg}^{-1}$. The average recovery \pm RSD for the BCR-420 is $92.0 \pm 4.6 \%$ and for the BCR-449 is $105 \pm 2.5 \%$ for all certified PCBs in waste oils.
\end{abstract}

Key words: PCBs, sulfoxide-bonded silica, validation, oil samples

\section{Introduction}

The election of standards to quantify PCBs is based on a number of factors among which the type of sample, the availability of reference compounds and the aim of the determination are included. Two European standard methods (EN 12766 and EN 61619) are currently used for the determination of PCBs in specific oil matrix. The first one is applicable to unused, used and treated petroleum products including synthetic lubricating oils and the second one is applicable to unused, reclaimed or used insulating liquids where it is specifically emphasized that the presence of mineral oil may reduce the sensitivity of the ECD. In addition to the official methods (where a combination of acidified silica/anion exchange $\left(\mathrm{SiOH}-\mathrm{H}_{2} \mathrm{SO}_{4} / \mathrm{SA}\right)$ and silica adsorbent is proposed) numerous sample preparation techniques are available for PCB analysis in oil samples ranging from extraction with aprotic solvents (e.g. dimethylsulfoxide, dimethylformamide) (LARSEN et.al., 1991; LAWN and TOFFEL, 1987), enzyme immunoassay (LAMBERT et.al., 1997), HS SPME (CRIADO et.al., 2004), sulphuric 
acid and alkali treatment (SHIN and KIM, 2006; SHU et.al., 1995), gel permeation chromatography (SHERIDAN et.al., 1995), normal-phase (Florisil, alumina) (LULEK, 1998; NERIN and DOMENO, 1999; STORR-HANSEN et.al., 1992), reversed-phase chromatography and many surface modified silica for SPE may be in use $\left(\mathrm{NH}_{2}, \mathrm{NH}_{2}-\right.$ $\mathrm{Cl}, \mathrm{NH}_{2}-\mathrm{SO}, \mathrm{SCX}-2, \mathrm{SCX}-2-\mathrm{NH}_{4}, \mathrm{SAX}, \mathrm{SAX}-\mathrm{SO}_{4}, \mathrm{CN}$, DIOL and PSA) for the separation of PCBs from mineral oils (TAKADA et.al. 2001; NA et.al., 2008; NUMATA et.al., 2006; NUMATA et.al., 2007; NUMATA NUMATA et.al., 2008).

PCBs are not easily separated from oil matrices because their physical and chemical characteristics are very similar. The remaining oil during the analytical procedure was not an immediate analytical problem, because when the sample fraction was analyzed by selective detectors like ECD, the co-extracted compounds are not directly detected. Also, lower limits of quantification are required. That is why a new modification of silica was used for sample preparation. Supelclean Sulfoxide SPE (PSA-SO) consists of a patent pending sulfoxide-bonded silica where PCBs are preferentially retained on the SPE phase whereas sample interferences (e.g. long chain hydrocarbons) are eluted in the early fraction.

The procedure was validated through regular analysis of blanks, fortified samples (transformer oil, motor used and unused oil) and certified materials (BCR-449 and BCR-420, waste mineral oils, high and low PCB levels). Two internal standards were used (PCB 30 and PCB 209). The working range, limit of quantification, repeatability, reproducibility and accuracy were determined.

\section{Materials and methods}

A surrogate standard solution was prepared by dissolving six PCB congeners (PCB 28, PCB 52, PCB 101, PCB 138, PCB 153 and PCB 180) from Dr. Ehrenstorfer and two PCB congeners (PCB 30 and PCB 209) in hexane. Reference materials BCR CRM-420 and BCR CRM-449 with a certified concentration of several PCBs were purchased from the Institute for Reference Materials and Measurements (Geel, Belgium). J.T.Baker supplied acetone and hexane. Individual solutions of internal standards were prepared in acetone followed by dilution with hexane.

Three different matrices of oil samples were taken for analysis. Waste oils were classified according to their origin into transformer oil, motor used and unused oil.

\subsection{Sample preparation}

The following SPE method is based on a modified Supelco procedure. Spiked and non-spiked oil samples $(0.25 \mathrm{~g})$ were dried with anhydrous sodium sulphate and diluted to $10 \mathrm{ml}$ with hexane. Samples were homogenized and placed into the SPE station. Supelclean Sulfoxide PP SPE $(3 \mathrm{~g} / 6 \mathrm{ml})$ from Supelco and SiOH PP SPE $(500 \mathrm{mg} / 3 \mathrm{ml})$ from Chromabond were used for the sample cleanup. The schematic SPE process is shown in Table 1.

A gas chromatograph AT6890 with two capillary columns of different polarities (HP-5MS and DB-1701) coupled to two $\mu$ ECDs was used. 
Oven temperature program was $90^{\circ} \mathrm{C}(1 \mathrm{~min}), 70^{\circ} \mathrm{C} / \mathrm{min}$ to $180^{\circ} \mathrm{C}, 5^{\circ} \mathrm{C} / \mathrm{min}$ to $230^{\circ} \mathrm{C}(0.1 \mathrm{~min}), 1.5^{\circ} \mathrm{C} / \mathrm{min}$ to $280^{\circ} \mathrm{C}$.

Four calibration standards were prepared to cover the optimum range with the lowest calibration level of $0.2 \mathrm{mg} \mathrm{kg}^{-1}$ per single PCB congener.

Table 1. Sample cleanup preparation by SPE.

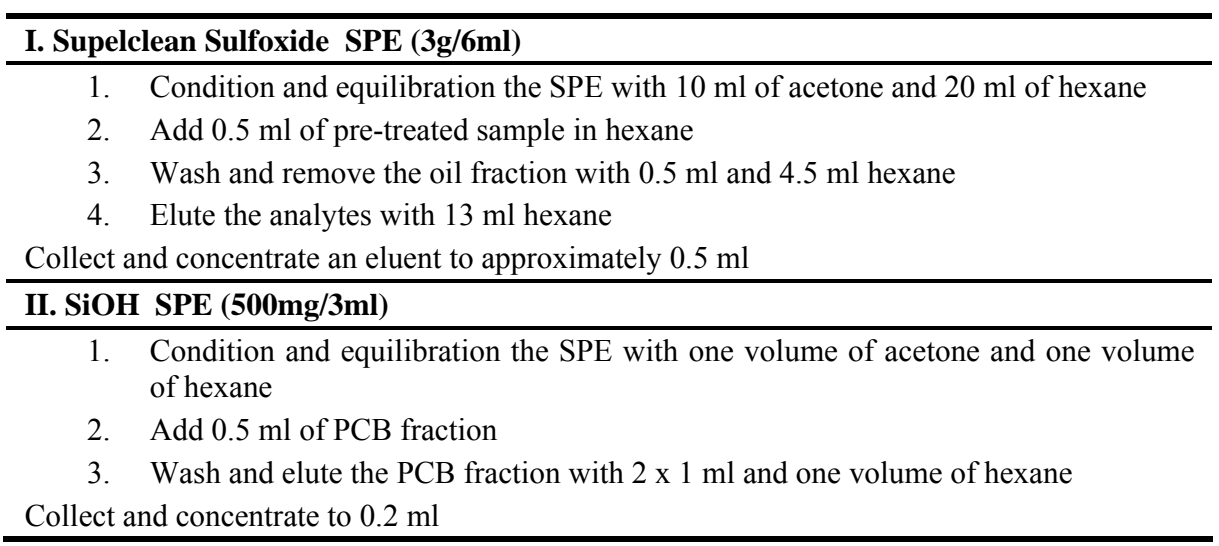

\section{Results and discussion}

As shown in the chromatogram (Fig. 1) good peak shape and sufficient separation of the critical pairs was obtained (resolution was 0.5 or greater). The working range of individual PCB congener was from $0.2 \mathrm{mg} \mathrm{kg}^{-1}$ to $100 \mathrm{mg} \mathrm{kg}^{-1}$. The accuracy was also very good. Repeatability was less than $10 \%$ for all spiked samples, for all congeners over the whole calibration range with some exceptions for the transformer oil.

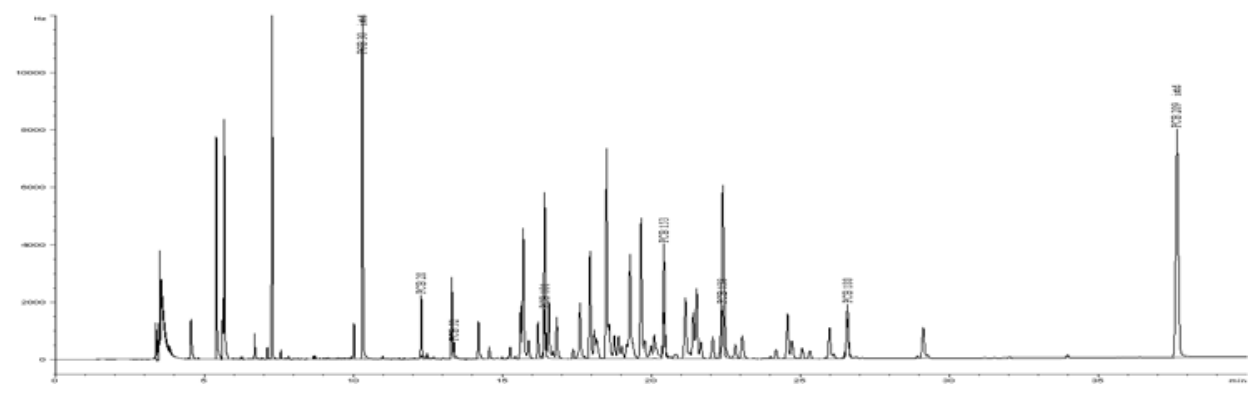

Fig. 1. GC-ECD-ECD chromatograms of the BCR standard, waste mineral oil.

An average recovery \pm RSD of $82.8 \pm 5.4 \%$ was achieved for all six PCBs in different matrices (Fig. 2).

The average recovery \pm RSD for the BCR-420 was $92.0 \pm 4.6 \%$ and for the BCR$449105 \pm 2.5 \%$ for all certified PCBs in waste oils (Fig. 3 and Fig. 4). 


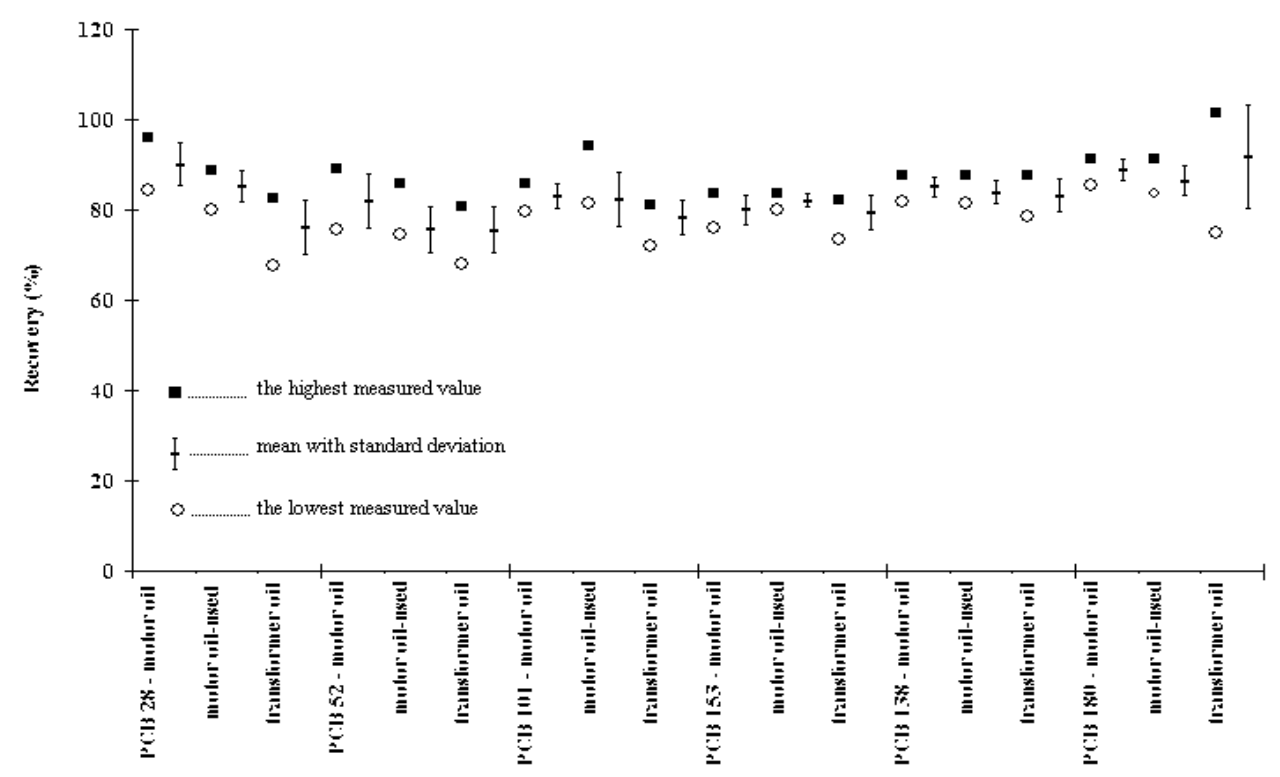

Fig. 2. Results of the repeatability and recovery studies on fortified different matrices.
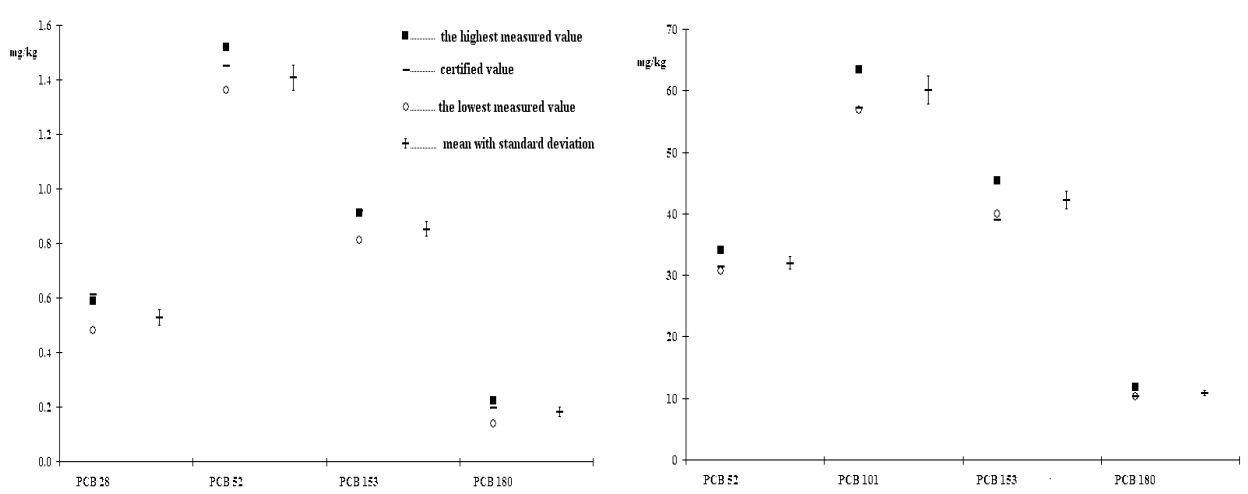

Fig. 3. Results of the repeatability and recovery Fig. 4. Results of the repeatability and recovery studies studies on the BCR-420. on the BCR-449.

\section{Conclusions}

By using new sulfoxide-bonded silica, PCBs are better separated from aliphatic hydrocarbons because the specificity of the stationary phase for these compounds is much higher than that used in both standard methods. This previously developed sulfoxide-bonded silica and ammonium-salt bonded silica stationary phase (PSA-SO) together with the additional silica one, offer a simple, fast and efficient sample preparation for the extraction of PCBs from waste, transformer and mineral oil samples (especially paraffin-based), which can replace that mentioned in both European standards without any possible damage to the GC system. 


\section{References}

CRIADO, M.R., PEREIRO, I.R., TORRIJOS, R.C.: Selective determination of polychlorinated biphenyls in waste oils using liquid-liquid partition followed by headspace solid-phase microextraction and gas chromatography with atomic emission detection. J. Chromatogr. A, 1056, 2004, 263-266.

CANALS, A., FORTEZA, R., CERDA, V.: The routine determination of PCBs in waste automotive engine oils. Chromatographia, 34, 1992, 35-40.

LAMBERT, N., FAN, T.S., PILETTE, J.: Analysis of PCBs in waste oil by enzyme immunoassay. Sci. Total Environ., 196, 1997, 57-61.

LULEK, J.: Levels of polychlorinated biphenyls in some waste motor and transformer oils from Poland. Chemosphere, 37, 1998, 2021-2030.

LARSEN, B., TILIO, R., KAPILA, S.: A DMSO-based cleanup procedure for determination of PCBs in waste oil. Chemosphere, 23, 1991, 8-10.

LAWN, R.E., TOFFEL, S.A.: Determination of polychlorinated biphenyls in waste oil by gas-liquid chromatography. Analyst, 112, 1987, 53-56.

NERIN, C., DOMENO, C.: Determination of polyaromatic hydrocarbons and some related compounds in industrial waste oils by GPC-HPLC-UV. Analyst, 124, 1999, 67-70.

NUMATA, M., AOYAGI, Y., TSUDA, Y., YARITA, T., TAKATSU, A.: Separation of polychlorinated biphenyls from mineral oil using alkylammonium ion-bonded silica stationary phases. Anal. Sci., 22, 2006, 785-788.

NUMATA, M., AOYAGI, Y., TSUDA, Y., YARITA, T., TAKATSU, A.: Preparation of sulfoxide residue bonded silica stationary phase for separation of polychlorinated biphenyls from mineral oils. Anal. Chem., 79, 2007, 9211-9217.

NUMATA, M., KANEKO, T., MI, Q., YE, M., KAWAMATA, S., MATSUO, M., YARITA, T.: Preparation of a sulfoxide group and ammonium-salt bonded silica stationary phase for separation of polychlorinated biphenyls from mineral oils. J. Chromatogr. A, 1210, 2008, 68-75.

NA, Y., KIM, K., HONG, J., SEO, J.: Determination of polychlorinated biphenyls in transformer oil using various adsorbent for solid phase extraction. Chemosphere, 73, 2008, S7-S12.

SHIN, S.K., KIM, T.S.: Levels of polychlorinated biphenyls (PCBs) in transformer oils from Korea. J. Hazard. Mat., 137, 2006, 1514-1522.

SHU, Y.Y., DOWDALL, J.E., CHIU, C., LAO, R.C.: Interference of transformer oil matrices to the internal standards on PCB quantification. Intern. J. Anal. Chem., 60, 1995, 185-194.

STORR-HANSEN, E., CLEEMANN, M., CEDERBERG, T., JANSSON, B.: Selective retention of non-ortho substituted coplanar chlorinated biphenyl congener on adsorbents for column chromatography. Chemosphere, 24, 1992, 323-333.

SHERIDAN, B.R., POOLE, G., DAWDALL, E., CHIU, C.: The effect of temperature on GPC for the separation of PCBs from transformer oil and subsequent analysis by GC-MSD. Int. J. Environ. Anal. Chem., 60, 1995, 195-202.

TAKADA, M.I., TODA, H., UCHIDA, R.: A new rapid method for quantification of PCBs in transformer oil. Chemosphere, 43, 2001, 455-459. 